\title{
ANALISIS ANTIBAKTERI EKSTRAK DAUN PACAR KUKU (Lawsonia inermis L) TERHADAP PERTUMBUHAN Salmonella sp
}

\author{
Andi Fatmawati ${ }^{1)}$, Waode Rustiah ${ }^{1)}$, Syaiful S. ${ }^{\text {1) }}$ \\ ${ }^{1)}$ Prodi DIII Teknologi Laboratorium Medis Politeknik Kesehatan Muhmmadiyah Makassar \\ Alamat Korespondensi: fatmawati.moe@gmail.com
}

\begin{abstract}
Abstrak
Daun pacar kuku (Lawsonia inermis L) merupakan salah satu tanaman Indonesia yang sering digunakan masyarakat untuk pengobatan radang, luka bakar, dan penyakit kulit. Tanaman ini memiliki aktivitas antibakteri karena mengandung flavonoid, tanin, alkaloid, dan quinon. Penelitian ini bertujuan untuk menganalisis kemampuan antibakteri ekstrak daun pacar kuku terhadap pertumbuhan Salmonella sp. Uji antibakteri ekstrak daun pacar kuku dilakukan dengan menggunakan 5 konsentrasi yaitu 15\%, 25\%, 50\%, 75\%, 100\% pada media agar yang mengandung kultur bakteri Salmonella sp. Hasil penelitian menunjukkan bahwa ekstrak daun pacar kuku pada konsentrasi 100\%, 75\%, dan 50\% memiliki kemampuan antibakteri terhadap pertumbuhan Salmonella sp, hal ini ditunjukkan dengan adanya zona bening yang terbentuk. Sedangkan pada konsentrasi $25 \%$ dan $15 \%$ tidak ditemukan kemampuan antibakteri terhadap pertumbuhan Salmonella sp.
\end{abstract}

Kata kunci: Ekstrak daun pacar kuku, Antibakteri, Pertumbuhan Salmonella sp

\section{PENDAHULUAN}

Obat-obatan tradisional yang berasal dari tanaman sudah digunakan oleh penduduk dibelahan dunia sebagai obat alternatif untuk penyakit-penyakit tertentu. Salah satu tanaman yang memiliki khasiat untuk digunakan sebagai obat tradisonal adalah daun pacar kuku. Pacar kuku (Lawsonia inermis) merupakan jenis tanaman yang termasuk dalam famili Lytraceae berupa tanaman perdu bercabang banyak atau pohon kecil bertinggi 1-4 meter (Cahyani et al., 2001).

Tanaman daun pacar kuku merupakan salah satu jenis daun yang terdapat di Indonesia dan dikenal sebagai daun inai yang digunakan untuk menyembuhkan radang ruas jari (paniritium) dan luka pada kulit. Selain itu pada bagian bunga, biji, kulit, batang dan akar berpotensi menyembuhkan sakit kepala, arthritis, diare, dan demam . Ekstrak daun pacar kuku mempunyai sifar bakterisid dan fungisid. Daun pacar kuku (Lawsonia inermis Linn) mengandung tanin yang dapat mencegah lapisan. Kulit yang terluka dari serangan bakteri yang akan membentuk jaringan baru pada kulit yang terluka. Ekstrak daun pacar kuku juga bersifat ekstringet yang dapat mengecilkan luka pada kulit. Skrining fitokimia yang dilakukan terhadap ekstrak daun pacar kuku mengandung senyawa glikosida, fitosterol, tanin, flavonoid, dan kukumin (Rahmania, 2015). Selain digunakan sebagai pewarna alami, secara farmakologi daun pacar kuku digunakan untuk pengobatan hiperglikemik , memiliki aktivitas antimikroba, efek penyembuhan luka, sitoksik, antioksidan dan antivirus (Caudhary, et al.,2010). Secara tradisional bagian daun, bunga dan biji berkhasiat secara antipiretik, penyembuhan luka bakar, sembelit, obat diare, dan disentri (Ditjen POM, 2000).

$$
\text { Salah satu bakteri yang }
$$
menyebabkan penyakit adalah infeksi dan kontaminasi yang disebabkan oleh Salmonella sp. dan ditemukan hampir diseluruh belahan dunia. Infeksi bakteri ini pada hewan atau manusia dapat mengakibatkan penyakit yang disebut salmonellosis (Jawetz,2018,).

Berdasarkan kajian diatas maka peneliti merasa penting untuk menganalisis kemampuan antibakteri

Jurnal Medika: Media Ilmiah Analis Kesehatan Volume 4 Nomor 2, Desember 2019 ISSN:2540-7910 29 
ekstrak daun pacar kuku terhadap pertumbuhan Salmonella $s p$. Prinsip metode yang digunakan adalah dengan menarik senyawa kimia aktif yang terdapat pada simplisia daun pacar kuku dengan menggunakan metode maserasi kemudian ekstrak yang dihasilkan akan diuji kemampuan antibakterinya terhadap pertumbuhan Salmonella sp. Selanjutnya akan dianalisis lebih mendalam.

\section{METODOLOGI PENELITIAN}

Penelitian ini merupakan penelitian eksperimen laboratorik dengan menyeleksi daun pacar kuku yang dikoleksi dari daerah Sinjai, selanjutkan akan diekstrak menggunakan metode maserasi dan dilanjutkan dengan uji antibakteri.

Sampel penelitian ini adalah ekstrak daun pacar kuku dengan konsentrasi 15\%, 25\%, 50\%, 75\%, dan $100 \%$ dan bakteri Salmonella sp.

\section{Pembuatan medium MHA (Muller} Hinton Agar)

Ditimbang sebanyak 3,42 gram serbuk MHA dan dimasukkan ke dalam Erlenmeyer lalu dilarutkan dengan aquades hingga volume $100 \mathrm{ml}$, dilakukan pemanasan hingga semua bahan larut, lalu disterilkan dalam autoklaf suhu $121^{\circ}$ selama 15 menit.

\section{Pembuatan larutan Mc Farland 0,5\%}

Larutan baku Mc Farland terdiri atas 2 komponen, yaitu $\mathrm{Bacl}_{2} 1 \%$ dan $\mathrm{H}_{2} \mathrm{SO}_{4} 1 \%$. Larutan $\mathrm{Bacl}_{2} 1 \%$ sebanyak $0,5 \mathrm{ml}$ dicampur dengan larutan $\mathrm{H}_{2} \mathrm{SO}_{4}$ $1 \%$ sebanyak $9,95 \mathrm{ml}$ dalam labu takar hingga homogen. Suspensi ini digunakan sebagai larutan standar pembanding kekeruhan suspensi jamur uji (Widiyanti dan Amran, 2018).

\section{Pengolahan sampel uji}

Daun pacar kuku yang sudah diambil, disortasi basah lalu dicuci dengan menggunakan air mengalir kemudian dikeringkan dengan dianginanginkan tanpa terkena matahari langsung sampai kering lalu disortasi kering. Selanjutnya dihaluskan kemudian dimasukkan kedalam wadah dan ditutup dengan baik.

\section{Ekstraksi bahan uji menggunakan metode meserasi}

Disiapkan bejana meserasi lalu di cuci sampai bersih, dikeringkan dan dibilas dengan etanol. Bahan uji daun pacar kuku yang telah dihaluskan ditimbang sebanyak 800 gram dan dimasukkan ke dalam bejana meserasi kemudian ditambahkan pelarut etanol 96\% sampai bahan uji tertutupi oleh pelarut. Bejana meserasi ditutup dengan rapat dan disimpan di tempat yang tidak terkena matahari langsung selama 5 hari, setiap $1 \times 24$ jam bahan uji diaduk. Setelah 5 hari bahan uji disaring dengan menggunakan kain kasa ke dalam tempat penampungan. Ampasnya dimasukkan kembali ke dalam bejana maserasi .Ekstrak yang diperoleh dikumpulkan dalam wadah, lalu filtrat dan endapan dipisahkan. Filtrat diambil dan diuapkan hingga kental dengan alat rotary evaporator.

\section{Pembuatan suspensi bakteri}

Diambil seujung mata ose biakan bakteri dengan menggunakan ose steril, kemudian dimasukkan ke dalam $\mathrm{NaCL}$ $0,9 \%$ steril,dihomogenkan, setelah itu dibuat kekeruhan dimana kekeruhannya setara dengan Mc Farland.

\section{Pembuatan konsentrasi sampel}

Untuk kosentrasi $15 \%$ diambil 15 ml ekstrak daun pacar kuku ke dalam Erlenmeyer, kemudian diencerkan dengan aquadest hingga $100 \mathrm{ml}$. Untuk konsentrasi $25 \%, 50 \%, 75 \%$, dan $100 \%$ masing-masing diambil ekstrak daun pacar kuku ke dalam Erlenmeyer sesuai dengan konsentrasi yang akan dibuat kemudian dicukupkan hingga $100 \mathrm{ml}$. Setelah semua konsentrasi dibuat, masukkan paper disk blank ke dalam masing-masing sampel yang telah dibuat lalu direndam selama 1 jam.

\section{Uji Antibakteri}

Diambil suspensi bakteri dengan menggunakan swab steril lalu diusapkan merata pada seluruh permukaan media MHA. Kemudian ditempelkan masing- 
masing paper disk yang sudah direndam pada masing-masing bahan uji ekstrak daun pacar kuku sesuai konsentrasi dan control positif (Cefadroxil) serta control negative (aquades) diletakkan secara aseptis dengan menggunakan pinset steril di atas permukaan media MHA dengan jarak tertentu dan diinkubasi selama 24 48 jam pada suhu $30^{\circ} \mathrm{C}$.

Analisis uji dikategorikan positif apabila uji hasil laboratorium pada ekstrak dan pacar kuku (Lawsonia inermis L) dapat menghambat pertumbuhan bakteri Salmonella $s p$ yang ditandai dengan terbentuknya zona bening di sekitar kertas cakram. Lalu diameter zona bening diukur dengan menggunakan jangka sorong.

Penilaian diameter zona hambat dengan antibiotic Cefadroxil:
Sensitif $: \geq 18 \mathrm{~mm}$ Intermediet $\quad: 15-17 \mathrm{~mm}$; Resisten $\quad: \leq 14 \mathrm{~mm}$

HASIL PENELITIAN

Tabel 1. Hasil Uji Antibakteri Ekstrak Daun Pacar Kuku (Lawsonia Inermis L) Terhadap Pertumbuhan Salmonella sp

\begin{tabular}{cccccc}
\hline \multirow{2}{*}{ Perlakuan } & \multicolumn{4}{c}{ Zona Hambat (mm) } & Keterangan \\
\cline { 2 - 5 } & Replikasi I & Replikasi II & $\begin{array}{c}\text { Replikasi } \\
\text { III }\end{array}$ & Rata-rata & \\
\hline $\begin{array}{c}\text { Kontrol positif } \\
\text { (Cefadroxil) }\end{array}$ & 40,3 & 30 & 32 & 34,1 & Sensitif \\
Konsentrasi100\% & 14,8 & 16 & 17,6 & 16,1 & Intermediet \\
Konsentrasi 75\% & 16 & 14,8 & 14,8 & 15,2 & Resisten \\
Konsentrasi 50\% & 15,6 & 15,2 & 12,4 & 14,4 & $\begin{array}{c}\text { Resisten } \\
\text { Tidak } \\
\text { Konsentrasi 25\% }\end{array}$ \\
Konsentrasi 15\% & 0 & 0 & 0 & 0 & $\begin{array}{c}\text { menghambat } \\
\text { Tidak } \\
\text { menghambat }\end{array}$ \\
\hline
\end{tabular}

Keterangan:

Diameter Paper Disk $\quad: 6 \mathrm{~mm}$

$\begin{array}{ll}\text { Sensitif } & : \geq 18 \mathrm{~mm} \\ \text { Intermediet } & : 15-17 \mathrm{~mm} \\ \text { Resisten } & : \leq 14 \mathrm{~mm}\end{array}$

$: \leq 14 \mathrm{~mm}$

\section{PEMBAHASAN}

Penelitian tentang analisis antibakteri ekstrak daun pacar kuku (Lawsonia inermis L) terhadap pertumbuhan Salmonella sp dilakukan di Laboratorium Mikrobiologi Politeknik Kesehatan Muhammadiyah Makassar. Pengamatan hasil uji antibakteri ekstrak daun pacar kuku terhadap pertumbuhan Salmonella sp dilakukan dengan melihat adanya zona bening yang terjadi akibat mekanisme antibakteri dalam menghambat pertumbuhan Salmonella sp.
Hasil yang didapatkan pada penelitian ini adalah menunjukkan adanya kemampuan antibakteri yang ditunjukkan pada konsentrasi $100 \%, 75 \%$, dan $50 \%$, masing -masing dengan diameter hambatan sebesar 16,1 mm; 15,2 mm; dan 14,4 mm. Sedangkan pada ekstrak dengan konsentrasi $25 \%$ dan $15 \%$ tidak menunjukkan terbentuknya zona bening. Ekstrak daun pacar kuku yang digunakan pada konsentasi $25 \%$ dan $15 \%$ belum mampu menghambat pertumbuhan Salmonella $s p$, hal ini disebabkan karena

Jurnal Medika: Media Ilmiah Analis Kesehatan Volume 4 Nomor 2, Desember 2019 ISSN:2540-7910 31 
kurangnya senyawa aktif yang terkandung pada konsentrasi yang rendah sehingga tidak memiliki kemampuan untuk menghambat pertumbuhan bakteri. Zona hambat juga terbentuk pada kontrol positif yang menggunakan antibiotic Cefadroxil sebesar 34,1 mm.

Pembuatan ekstrak daun pacar kuku dilakukan dengan metode maserasi. Ekstraksi merupakan proses penarikan senyawa metabolit sekunder dengan bantuan pelarut yaitu etanol 70\%. Ekstrak daun pacar kuku dibuat dalam konsentrasi tertentu dengan menggunakan DMSO. DMSO (Dimethyl sulfoxide) merupakan salah satu pelarut yang dapat melarutkan hampir semua senyawa baik polar maupun non polar, karena tidak memberikan pengaruh terhadap pertumbuhan biakan bakteri.

Hasil uji penelitian ini, juga bersesuaian dengan penelititan yang telah dilakukan Silva dan Devi (2017) bahwa ekstrak daun pacar kuku dapat menghambat pertumbuhan bakteri Pseudomonas auriginosa dengan konsentrasi $15 \%, 25 \%, 50 \%, 75 \%$ dan $100 \%$ menghambat sangat kuat dengan zona hambat sebesar 21,6 mm. Ekstrak daun pacar kuku dapat bereaksi terhadap bakteri, hal ini dapat disebabkan karena struktur dari dinding sel bakteri yang dapat dirusak oleh senyawa aktif dari ekstrak daun pacar kuku.

Kandungan yang terdapat pada daun pacar kuku diantaranya flavonoid, alkaloid, quinon, kumarin, triterpenoid, fenol, tanin, yang memiliki peran tersendiri dalam mengatasi pertumbuhan bakteri (Pratiwi, 2014). Flavonoid memiliki mekanisme membentuk komplek dengan protein ekstraseluler sehingga akan merusak membrane sel bakteri. Selain flavonoid, terdapat juga alkaloid yang memiliki senyawa yang dapat menganggu komponen penyusun peptidoglikan pada sel bakteri sehingga lapisan dinding sel tidak terbentuk secara utuh yang menyebabkan kematian sel bakteri tersebut . Terdapat pula senyawa tanin yang memiliki aktivitas antibakteri dengan cara menggandakan kompleks hidrofobik dengan protein, menginaktivasi adhesion, enzim dan protein transpordinding sel sehingga menganggu pertumbuhan mikroorganisme. Quinon memiliki efek sebagai antibakteri karena quinon mampu menghasilkan radikal bebas yang stabil dan membentuk kompleks irreversible dengan asam amino nukleofilik pada protein sehingga protein kehilangan fungsi (Muslim, 2014).

Mekanisme kerja obat antibakteri, yaitu inhibis sintetis dinding sel, inhibisi fungsi membrane sel, inhibisi sintetis protein, dan inhibisi sintetis asam nukleat (Jawetz et al, 2008). Pada penelitian ini digunakan Cefadroxil sebagai kontrol positif. Mekanisme kerjanya adalah menghambat sintetis dinding sel bakteri. Kontrol positif ini bertujuan untuk melihat gambaran terbunuhnya bakteri uji yang dilihat dari zona hambat. Hasil aktivitas antibakteri Cefadroxil sebagai kontrol positif dapat menghambat pertumbuhan bakteri dengan hasil ratarata $34,1 \mathrm{~mm}$ dengan kategori yang sangat kuat (sensitif), sehingga dapat dikatakan bahwa dengan kontrol positif antibiotic (Cefadroxil) dapat menghambat pertumbuhan Salmonella sp. Kontrol negatif yang digunakan pada penelitian ini adalah aquadest. Kontrol negatif bertujuan untuk membuktikan bahwa aquadest yang digunakan untuk melarutkan ekstrak daun pacar kuku tidak memiliki aktivitas terhadap bakteri uji yang digunakan. Beradasarkan hasil yang didapatkan pada penelitian ini, kontrol negative tidak menghasilkan zona hambat terhadap bakteri Salmonella sp sehingga tidak ada pengaruh antara pelarut dengan bakteri uji yang digunakan.

\section{KESIMPULAN}

Berdasarkan analisis penelitian yang telah dilakukan, disimpulkan bahwa ekstrak daun pacar kuku (Lawsonia inermis L) memiliki kemampuan antibakteri terhadap pertumbuhan

Jurnal Medika: Media Ilmiah Analis Kesehatan Volume 4 Nomor 2, Desember 2019 ISSN:2540-7910 32 
Salmonella sp pada konsentrasi $100 \%, 75 \%$, dan $50 \%$ dengan besaran zona hambat masing-masing $16,1 \mathrm{~mm}$; 15,2 mm; dan 14,4.

\section{DAFTAR PUSTAKA}

Chaudhary, G., Goyal, S. \& Poonia, P. 2010. Lawsonia inermis Linnaeus: A Phyopharmacological Review, International Jurnal of Pharmaceutical Sciences and Drug Research, 2, hlm.91-98.

Ditjen POM. (2000). Parameter Standar Umum Ekstrak Tumbuhan Obat. Cetakan Pertama. Jakarta: Departemen Kesehatan RI.

Jawetz, Z.E, Melnick, J.L, and Adelberg, E.A, 2008. Mikrobiologi Kedokteran, 23 th, Editor R.N. Elferia, EGC, Jakarta

Muslim, I. 2014. Aktivitas Antibakteri Ekstrak Daun Pacar Kuku (Lawsonia inermis L) Terhadap Pertumbuhan Enterococcus faecalis. Skripsi, Universitas Syiah
Kuala, Banda Aceh.

Pratiwi, D.A.N., 2014. Aktivitas Antibakteri Ekstrak Etanol Daun Pacar Kuku (Lawsonia inermis L) dan Bioautigrafi Terhadap Baccilus subtillis dan Shigella sonnei. Skripsi Universitas Muhammadiyah Surakarta, Surakarta.

Rahmina, P. 2015. Pengaruh Ekstrak Daun Pacar Kuku 7,5 Terhadap Penyembuhan Ulkus Traumatik Pada Mukosa Oral . Skripsi, Universitas Syiah Kuala, Banda Aceh.

Widiyanti, T. dan Amran P. 2018. Penuntun Praktikum Bakteriologi III .Akademi Analis Kesehatan Muhammadiyah. Makassar. 